\title{
PENGEMBANGAN BUMKAM BERBASIS POTENSI LOKAL DI KAWASAN PERBATASAN INDONESIA-PAPUA NEW GUINEA
}

\author{
Ilham $^{1}$, M. Zaenul Muttaqin ${ }^{2}$, Usman Idris $^{3}$ \\ ${ }^{1)}$ Prodi Ilmu Adminstrasi Publik, Fakultas Ilmu Sosial dan Ilmu Politik, Universitas Cenderawasih \\ ${ }^{2)}$ Prodi Antropologi, Fakultas Ilmu Sosial dan Ilmu Politik, Universitas Cenderawasih \\ e-mail: ilhamparepos@gmail.com
}

\begin{abstract}
Abstrak
Pelaksananaan sosialiasi yang bertajuk pengembangan "Badan Usaha Milik Kampung (BUMKam) Berbasis Potensi Lokal Di Kawasan Perbatasan Indonesia-Papua New Guinea (PNG)" dihadiri oleh Kepala distrik/camat Yaffi dan perangkatnya, Pemimpin adat (Ondoafi), tokoh pemuda, Tokoh agama, dan juga Kepala Desa dan anggota Badan Permusyawaratan Kampung (Bamuskam), serta masyarakat di Distrik Yaffi, Kabupaten Keerom, Kota Jayapura, Provinsi Papua. Pada Pelaksanaan kegiatan sosialisasi, dipaparkan materi mengenai alur pendirian, landasan hukum dan regulasi, permodalan, manfaat dan jenis usaha BUMKam (Badan Usaha Milik Kampung) yang tepat untuk dijalankan berdasarkan potensi lokal daerah setempat. Setelah itu, dilakukan sesi tanya jawab (feedback) sehingga terungkap bahwa BUMKam belum terlalu eksis dikalangan masyarakat, konsep pembangunan desa yang dilakukan oleh pemerintah kampung masih terfokus pada pembangunan fisik saja. Dengan adanya kegiatan pengabdian ini, diharapkan dapat memberikan pemahaman kepada masyarakat begitu juga kepada aparatur kampung bahwa kehadiran BUMKam akan menjadi suatu lembaga yang dapat mengangkat program prioritas kampung, potensi lokal serta kemajuan perekonomian kampung yang berpangkal terhadap kesejahteraan masyarakat lokal. Setelah mengikuti sosialiasi ini, peserta diharapkan dapat menambah wawasan yang dapat dijadikan sebagai landasan, baik dalam proses pendirian, maupun dalam pengelolaan BUMKam.
\end{abstract}

Kata kunci : Sosialisasi, BUMKam, Potensi Lokal

\begin{abstract}
The implementation of the socialization entitled "The Development of Village Enterprises (BUMKam) Based on Local Potentials in the Indonesia-Papua New Guinea (PNG) Borderland" was attended by the District Head of Yaffi and his apparatus, traditional leaders Ondoafi, youth figure , Religious figure, and also the Village Heads and members of the Village Consultative Body (Bamuskam), as well as people in the Yaffi District, Keerom Regency, Jayapura City, Papua Province. The implementation of the socialization activities, explained the material regarding the founding flow, legal and regulatory basis, capital, benefits and types of business BUMKam (Village-Owned Enterprises) that are appropriate to run based on the local potential of the local area. After that, a question and answer session (feedback) was conducted so that it was revealed that BUMKam did not yet exist in the community, the village development concept carried out by the village government was still focused on physical development. With this community service activity, it is expected to be able to provide understanding to the community as well as to the village apparatus that the presence of BUMKam will be an institution that can raise the priority program of the village, local potential and economic progress of the village which is rooted in the welfare of the local community. After participating in this socialization, participants are expected to be able to add insight that can be used as a foundation, both in the establishment process, and in the management of BUMKam.
\end{abstract}

Keywords: socialization, BUMKam, Local Potentials

\section{PENDAHULUAN}

Desa atau di wilayah Papua dikenal dengan istilah Kampung dalam Undang-undang nomor 6 Tahun 2014 tentang Desa dapat didefenisikan bahwa desa adat atau yang disebut dengan nama lain selanjutnya disebut Desa adalah kesatuan masyarakat hukum yang memiliki batas wilayah yang berwenang untuk mengatur dan mengurus urusan pemerintahan, kepentingan masyarakat setempat berdasarkan prakarsa masyarakat, hak asal usul, dan/atau hak tradisional yang diakui dan dihormati 
dalam sistem pemerintahan Negara Kesatuan Republik Indonesia (jdih.kemenkeu.go.id, 2020). Sementara, Badan Permusyaratan Kampung (Bamuskan) yang biasa dikenal dengan istilah Badan Permusyawartan Desa (BPD) merupakan lembaga legislatif yang berada ditingkat desa, Undangundang Nomor 110 Tahun 2016 tentang Badan Permusyawartan Desa menjelaskan bahwa BPD merupakan lembaga yang melaksanakan fungsi pemerintahan yang anggotanya merupakan wakil dari penduduk Desa berdasarkan keterwakilan wilayah dan ditetapkan secara demokratis. Dalam memajukan perekonomian, desa/kampung kemudian diharuskan untuk membentuk Badan Usaha Milik Kampung (BUMKam) atau BUMDes, hal ini ditandai dengan lahirnya Peraturan Menteri (Permen) PDTT Nomor 4 Tahun 2015 tentang Badan Usaha Milik Desa. Pendirian BUMKam juga dilandasi oleh Undang-undang Nomor 32 Tahun 2004 tentang pemerintahan daerah pada pasal 213 ayat (1) disebutkan bahwa desa mendirikan Bumdes yang sesuai dengan kebutuhan begitu juga potensi desa yang ada. Menurut, Kusman \& Widaningsih (2019) Bumdes merupakan perusahaan yang dijalankan oleh masyarakat desa dan kepengurusannya terpisah dari pemerintah desa. Olehnya dalam pengelolaan Bumdes harus sesuai dengan SOP yang dalam rujukan pengelolaan keuangan yang transparan dan akuntabel sehingga menatausahaan dapat berjalan secara maksimal dengan strandarisasi yang jelas (Sakti, dkk, 2020).

Pelaksanaan kegiatan pengabdian ini, terfokus membahas tentang proses pendirian dan pengembagan Badan Usaha Milik Kampung (BUMKam) yang dilaksanakan di Distrik/Kecamatan Yaffi, Kabupaten Keerom, Provinsi Papua dimana merupakan kawasan perbatasan Indonesia dan Papua New Guinea. Mengawali pembahasan tentang BUMKam, sedkit penulis memberi gambaran tentang lokasi pelaksanaan pengabdian bahwa terisolir merupakan kata yang pantas untuk disematkan terhadap Kampung yang berada dalam wilayah pemerintahan Distrik Yaffi. Akses yang masih sulit, sarana informasi dan komunikasi serta dukungan infrastruktur yang tidak memadai, belum lagi dibidang pendidikan dan kesehatan yang masih jauh dari kata layak. Dewasa ini pelbagai langkah yang telah dilakukan pemerintah dalam upaya memajukan kampung, salah satunya adalah melalui kucuran anggaran kampung yang hampir mengalami meningkat setiap tahunnya. Baik Dana Desa (DD) yang bersumber dari Anggaran Pendapatan Belanja Negara (APBN) begitu juga dengan Alokasi Dana Desa (ADD) yang bersumber dari Anggaran Pendapatan Belanja Daerah (APBD). Meski didukung anggaran yang cukup besar namun pembangunan kampung diwilayah Distrik Yaffi sejauh ini masih terlihat jalan ditempat, bahkan hadirnya DD dan ADD belum mampu menjadi solusi dalam menjawab pelbagai persoalan dalam mensejahterakan masyarakat. Minimnya pengetahuan aparatur kampung baik dalam pengelolaan anggaran dan pemanfaatan potensi lokal yang ada menjadi salah satu faktor pemicu.

Berdasarkan uraian diatas sehingga pembentukan Badan Usahan Milik Kampung (BUMKan) menjadi hal urgen untuk dilakukan, mengingat kehadiran BUMKam dinilai dapat menjadi solusi dalam mendorong perekonomian kampung yang tentunya berpangkal terhadap peningkatan kesejahteraan masyarakat lokal. Hal tersebut sejalan dengan pendapat Fatimah (2018) yang mengungkapkan bahwa BUMDes menjadi bagian lembaga yang dapat menopang kesejahteran warga desa, dan tentunya harapan tersebut dapat diiringi dengan meningkatnya Indeks Pembangunan Manusia (IPM). Pendirian BUMKam ini, seharusnya lebih difokuskan pada pemberdayaan masyarakat desa berdasarkan potensi lokal yang ada, tentunya sesuai dengan topografi, demografi begitu juga dengan kultur dengan melihat potensi desa sebagai landasan untuk pendirian sebuah BUMKam, maka diharapkan pemberdayaan masyarakat desa dapat melahirkan pelbagai produk unggulan berbasis kearifan lokal (Nursetiawan, 2018).

Sementara itu, menurut Agunggunanto \& Darwanto (2016) bahwa faktor keterbatasan sumber daya manusia yang mengelola BUMDes dianggap suatu menjadi kelemahan proses pengembangan suatu BUMDes. Berangkat dari pendapat tersebut, sehingga penting untuk dilakukan pendampingan yang diawali dengan sosialisasi pembentukan dan pengelolaan lembaga BUMKam di Kampungkampung yang ada wilayah Distrik/Kecamatan Yaffi, Kabupaten Keerom, Provinsi Papua. Berdasarkan hasil kajian Zulkarnaen (2016) juga dijelaskan bahwa lembaga seperti BUMDES memang memerlukan pembimbingan ataupun konsultasi dari pihak akademisi, baik dari aspek pembangunan dan pemberdayaan masyarakat terutama dalam pengembangan kemampuan dalam berusaha, peningkatan pengetahuan, keterampilan begitu juga dengan sikap yang akan berefek pada peningkatan pendapatan. Olehnya, dalam menjalankan kepengurusan BUMKam sangat perlu kesiapan SDM, pengurus sangat dianjurkan untuk memiliki keterampilan untuk menyusun rencana dan 
pengembangan serta keberlanjutan usaha yang dijalankan (Sudirno, dkk, 2020). Karena, dengan adanya Bumdes sebagai usaha milik bersama, secara tak langsung dapat menjadi penggerak dalam meningkatkan kesejahteraan masyarakat dan pertumbuhan perekonomian desa (Ridzal \& Hasan, 2020).

\section{METODE}

Pada pelaksanaan suatu kegiatan, maka penting adanya metode yang digunakan sebagai suatu alat untuk mencapai tujuan sebagamain yang telah direncanakan sebelumnya, adapun metode yang digunakan adalah outreach methods. Menurut Zubaedi (2013), metode ini (outreach methods) merupakan kegiatan yang sifatnya melakukan kontak, baik dalam bentuk pelayanan serta pendampingan kepada masyarakat dengan tujuan untuk meningkatkan partisipasi masyarakat dalam pelbagai kegiatan yang berorientasi untuk memperbaiki kondisi kehidupannya. Metode secara teoritis menurut Suharsimi (dalam Isnaini \& Herlina : 2020) dijelaskan bahwa suatu cara-cara utama yang dapat digunakan dalam mencapai suatu tujuan.

Dalam pelaksanaan kegiatan pengabdian ini, adapun langkah-langkah yang dilakukan, diantaranya a) tahapan perencanaan, b) mendiskusikan program dengan mitra, c) menyiapkan materi sosialisasi, d) pelaksanaan sosialisasi tentang BUMKam (Pembentukan, Pengelolaan, Pengembangan dan Sumber Dana), e) pemetaan potensi lokal, dan f) melakukan evaluasi.

\section{HASIL DAN PEMBAHASAN}

\section{Tahapan Kegiatan}

Pelaksanaan pengabdian ini, melibatkan mahasiswa angkatan 2016 pada Program Studi (Prodi) Ilmu Administrasi Publik, Fakultas Ilmu Sosial dan Ilmu Politik (FISIP), Universitas Cenderawasih Jayapura-Papua. Kegiatan tersebut berlangsung selama 2 hari yang dihadiri oleh Kepala Distrik (Camat) Yaffi beserta perangkatnya, Ondoafi (pimpinan adat), Tokoh pemuda, Tokoh agama, para Kepala Kampung (Kepala Desa), Anggota Badan Permusyawaratan Kampung (Bamuskam), serta masyarakat se-Distrik Yaffi, yang berasal dari: Kampung Amgotro, Kampung Fafenumbun, Kampung Akarinda, Kampung Jifanggry, Kampung Yabanda, dan Kampung Mongoafi. Pelaksanaan kegiatan berlangsung di Kampung Yabanda yang merupakan pusat pemerintahan Distrik Yaffi, adapun tahapan kegiatan dapat dilihat lebih rinci pada gambar berikut ini :

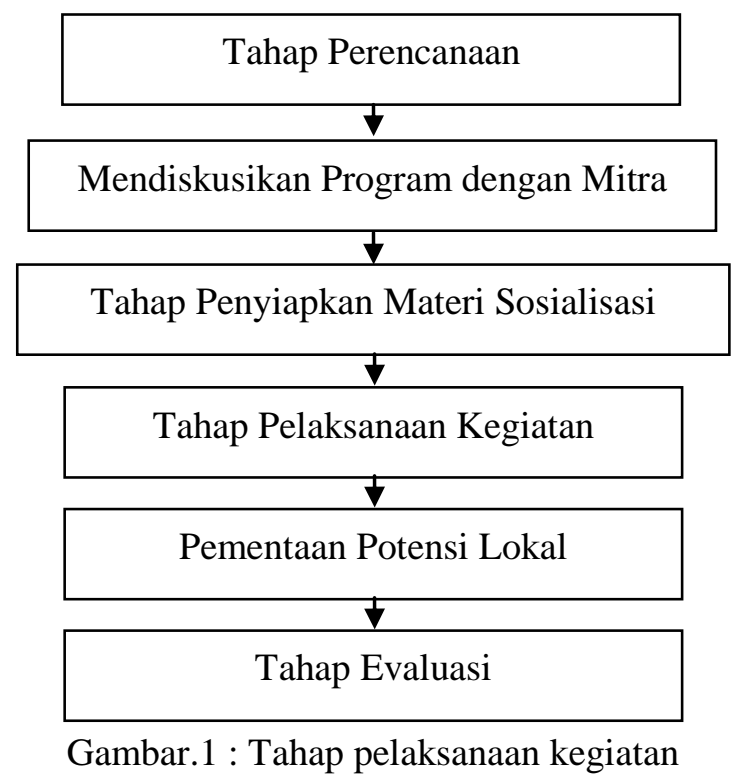

\section{Pembahasan}

Dalam mendorong kesejahteraan masyarakat melalui Badan Usaha Milik Kampung (BUMKam) masih jauh dari harapan, bahkan masyarakat belum begitu mengenal lembaga ini. Hal tersebut dikarenakan kurangnya sosialisasi ketingkat masayarakat kampung sehingga wacana BUMKam hanya bergelut dikalangan elit kampung saja, ada beberapa faktor yang menyebapkan terjadi demikian seperti kurangnya pemahaman aparat kampung lantaran konsep pembangunan 
Kampung yang selama ini mereka pahami masih sebatas pada pembangunan fisik. Belum terciptanya komunikasi yang baik antara pemerintah kampung dengan masyarakat sehingga menjadikan isu BUMKam itu sendiri belum cukup seksi ditengah masyarakat selaku lembaga yang mampu mendorong peningkatan ekonomi kampung yang berpangkal terhadap kesejahteraan masyarakat setempat. Hal tersebut terbukti, pada sesi tanya-jawab (feed back) pada umumnya peserta mengakui jika sejauh ini pendirian BUMKam terkendala dari segi Sumber Daya Manusia (SDM) yang mumpuni, dan masih kurangnya pemahaman masyarakat begitu juga aparatur kampung terkait dengan BUMKam.

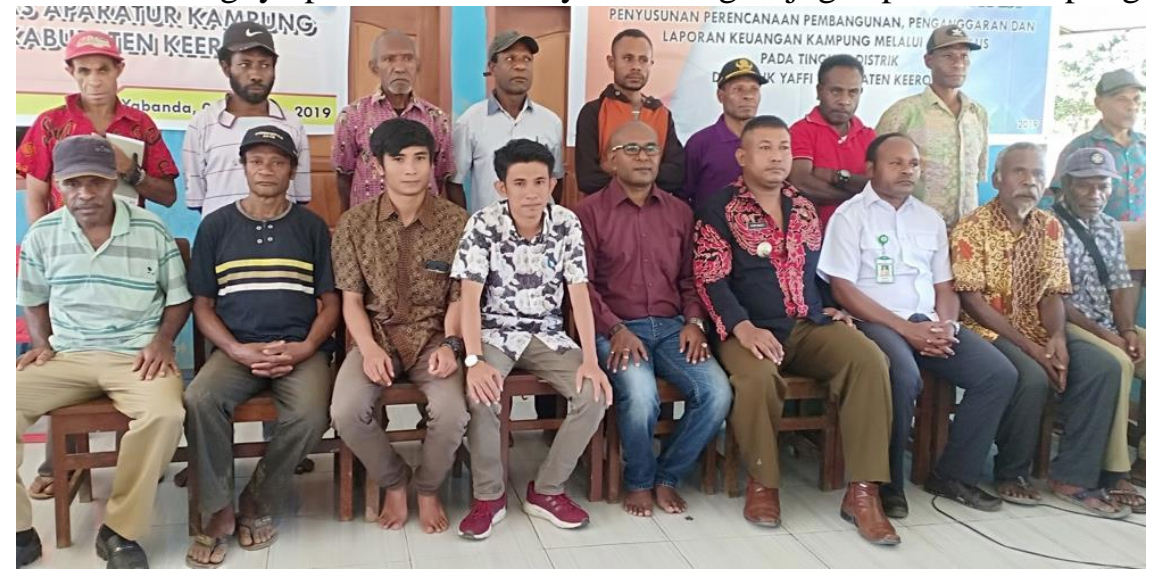

Gambar.2 : Foto bersama Kepala Distrik Yaffi, Kepala Kampung \& Bamuskam

Pada pelaksanaan sosialisasi ini, terdapat beberapa materi yang disampaikan, diantaranya: 1) Alur pendirian BUMKam; 2) Landasan hukum dan regulasi BUMKam; 3) Sumber permodalan BUMKam; 4) Manfaat dan jenis usaha yang tepat untuk dijalankan berdasarkan potensi local. Termasuk pemanfaatan Dana Desa (DD) dan Alokasi Dana Desa (ADD) untuk pendirian BUMKam, sebagaimana amanat Undang-undang Nomor 6 Tahun 2014 tentang Desa yang mengharuskan setiap Kampung memiliki BUMKam. Dilansir dari situs finance.detik.com, Setiawan (2019) mengungkapkan bahwa hal ini sejalan dengan penyampaian Menteri Desa, Pembangunan Daerah Tertinggal dan Transmigrasi era kabinet Jokowi-JK Eko Putro Sandjojo meminta untuk memperbesar anggaran yang diperuntukkan bagi pengembangan BUMDes, termasuk harus difikirkan adalah bursa inovasi desa agar dana desa dapat dimanfaatkan semaksimalkan mungkin dalam memperbesar BUMKam. Untuk menggenjot pertumbuhan ekonomi lokal dikawasan perbatasan menjadi penting untuk memanfaatkan solusi lokal yang ada, guna mempercepat pembangunan ekonomi lokal melalui BUMDes, seperti yang telah dijelaskan sebelumnya bahwa dalam skala Papua kemudian disebut BUMKam. Kehadiran BUMKam ditengah-tengah masyarakat diharapkan akan menjadi lembaga ekonomi sebagai kunci untuk memicu pergerakan ekonomi kampung. Namun, sebagian wilayah khususnya di wilayah Distrik Yaffi pengetahuan masyarakat tentang lembaga tersebut belum terlalu eksis, serta kurangnya SDM yang memiliki kemampuan manajerial juga menjadi kendala tersendiri.

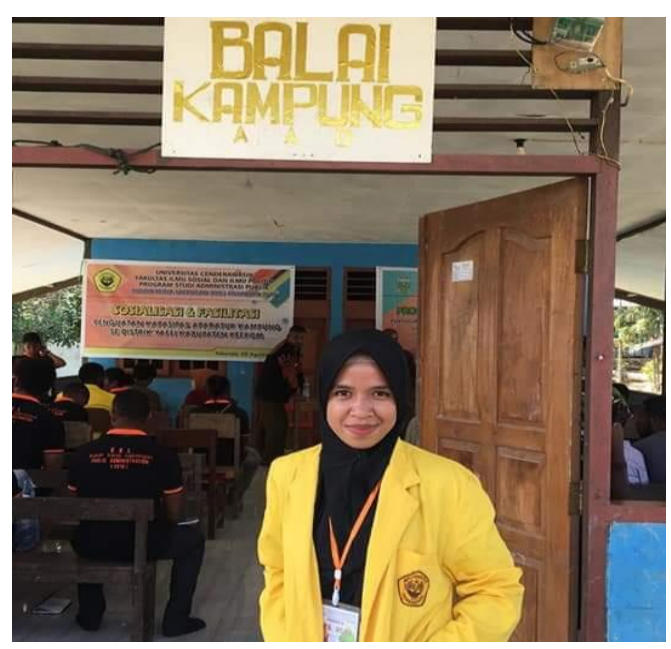


Gambar.3 : Pelaksanaan Sosialisasi di Balai Kampung Yabanda, Distrik Yaffi.

Pelaksanaan pembangunan masih terfokus pada pembangunan fisik (infrastruktur), sementara diketahui bahwa pembangunan sumber daya manusia yang mumpuni menjadi suatu keniscayaan dalam mengsukseskan setiap program-program yang ada di tingkat kampung. Berangkat dari hal tersebut sehingga penting untuk dilakukan pendampingan pembentukan hingga pengelolaan BUMKam secara berkelanjutan, serta menggelar pelatihan BUMKam untuk menyaring pelbagai permasalahan serta merumuskan solusi melalui sinergitas sebagai bentuk sharing knowledge. Konsep sinergitas nantinya dapat mendorong pelbagai pihak untuk lebih berpartisipasi dengan menjadikan kampung sebagai pelaku utama. Menurut Zubaedi (2013) untuk meningkatkat partisipasi melalui program pengembangan masyarakat diawali dengan megubah kesadaran masyarakat akan hak-haknya untuk hidup secara lebih bermutu. Adanya realitas kompleksitas permasalahan yang dihadapi serta perlunya tindakan konkret dalam mengupayakan perbaikan kehidupan.

\section{SIMPULAN}

Badan Usaha Milik Desa (BUMDes) dalam skala Papua dikenal dengan istilah BUMKam belum terlalu eksis dikalangan masyarakat, konsep pembangunan selama ini dipahami masih terfokus pada pembangunan fisik (infrastruktur), serta kurangnya pemahaman aparatur kampung menjadi kendala tersendiri dalam mewujudkan BUMKam sebagai lembaga yang dapat mendorong peningkatan ekonomi kampung. Sehingga dibutuhkan Sumber Daya Manusia (SDM) sebagai solusi dalam menakar pelbagai permasalahan tersebut. Adapun beberapa langkah yang penting untuk dilakukan, diantaranya : rutin menggelar pelatihan BUMKam, memberikan pemahaman filosofi BUMKam kepada pemerintah kampung, melakukan pemetaan terhadap semua potensi lokal untuk menghindari kesalahan dalam menentukan unit usaha. Ketika filosofi BUMKam telah dipahami termasuk cara memetakan potensi kampung serta mengerti akan siklus penglolaan usaha maka masalah-masalah yang akan muncul dapat diminimalisir. Tentunya melalui inovasi berbasis kearifan lokal dalam tata kelola BUMKam dengan memberdayakan dan melestarikan unsur-unsur nilai kebudayaan dan adat istiadat dalam mengelola potensi kampung. Keterpaduan inilah kemudian akan mewujudkan suatu perubahan menuju kesejahteraan masyarakat lokal, demikian pula diharapkan akan melahirkan kepecayaan diri bagi masyarakat dalam mencapai kondisi kehidupan yang lebih baik.

\section{UCAPAN TERIMAH KASIH}

Kegiatan pengabdian kepada masyarakat yang dilaksanakan di Kampung Yabanda tidak akan berjalanan dengan baik tanpa adanya dukungan dari pelbagai pihak. Untuk itu, penulis mengucapkan banyak terima kasih kepada Kepala Distrik Yaffi Herry S. Wabes, Pemimpin Adat (Ondoafi) Kampung Yabanda, Kepala Kampung, Bamuskam, tokoh pemuda, tokoh agama, masyarakat, serta mahasiswa angkatan 2016 pada Program Studi Ilmu Administrasi Publik, Fakultas Ilmu Sosial dan Ilmu Politik Universitas Cenderawasih Jayapura-Papua.

\section{DAFTAR PUSTAKA}

Agunggunanto, E. Yusuf \& Darwanto (2016) Pengembangan Desa Mandiri Melalui Pengelolaan Badan Usaha Milik Desa (Bumdes). Jurnal Dinamika Ekonomi dan Bisnis, 13(1), 67-81.

Fatimah, P.L. Rika. (2018). Mengembangkan Kualitas Usaha Milik Desa (Q-BUMDES) untuk Melestarikan Ketahanan Ekonomi Masyarakat dan Kesejahteraan Adaptif: Perancangan Sistem Kewirausahaan Desa dengan Menggunakan Model Tetrapreneur. Jurnal Studi Pemuda 7(2), 122-132.

Isnaini, Heri \& Yulia Herliani. (2020). Penyuluhan Pembelajaran Menulis Puisi Berbasis Karakter Di Smk Profita Kota Bandung Tahun Ajaran 2019-2020. Communnity Development Journal, 1(2), 78-83.

Jdih.kemenkeu.go.id. (2019). Peraturan Menteri Keuangan Republik Indonesia Nomor 40 /Pmk.07/2020 Tentang Perubahan Atas Peraturan Menteri Keuangan Nomor 205/Pmk.07/ 2019 Tentang Pengelolaan Dana Desa. [Online] Available at :https://jdih.kemenkeu.go.id/fullText/2020/40 PMK.07 2020Per.pdf (Diakses, 3 Juni 2020) 
Kusman, H Haryani., Widaningsih, Ida. (2019). Resep Membangun Desa. Jakarta : Campustaka Mendes PDTT RI. (2015). Peraturan Menteri (Permen) PDTT Nomor 4 Tahun 2015 tentang Badan Usaha Milik Desa.

Nursetiawan, Irfan. (2018). Strategi Pengembangan Desa Mandiri Melalui Inovasi Bumdes. Jurnal Ilmiah Ilmu Pemerintahan , 4(2), 72-81.

Ridzal, N. A., \& Hasan, W. A. (2020). Eksistensi Badan Usaha Milik Desa (Bumdes) sebagai Penggerak Ekonomi Desa. Jurnal Pengabdian Kepada Masyarakat: Membangun Negeri, 4(1), 98106.

Sakti, D. P. B., Nurmayanti, S., Putra, I. N. N. A., \& Wardani, L. (2020). Pelatihan Penyusunan Standard Operating Procedure (SOP) Keuangan Bagi Pengelola BUMDes Desa Karang Bayan Kecamatan Lingsar Kabupaten Lombok Barat. Jurnal PEPADU, 1(2), 185-190.

Setiawan Robi. (2019). Mendes Ingin Alokasi Dana Desa Lebih Banyak Untuk Bumdes. [Online] Available at :https://finance.detik.com/berita-ekonomi-bisnis/d-4416915/2019-mendes-inginalokasi-dana-desa-lebih-banyak-untuk-bumdes (Diakses, 4 Juni 2020).

Sudirno, D., Masduki, M., Suparto, L., Nahdi, D. S., \& Sumianto, T. (2020). Peningkatan Kapasitas Badan Usaha Milik Desa (BUMDes) Mapan Desa Panjalin Kidul. BERNAS: Jurnal Pengabdian Kepada Masyarakat, 1(1), 53-58.

Zubaedi (2013). Pengembangan Masyarakat, Wacana dan Praktik. Jakarta : Kencana.

Zulkarnaen, Reza M. (2016). Pengembangan Potensi Ekonomi Desa Melalui Badan Usaha Milik Desa (Bumdes) Pondok Salam Kabupaten Purwakarta. Jurnal Aplikasi Ipteks untuk Masyarakat, $5(1), 1-4$. 